\title{
多岐にわたる分野へのマイクロバブル応用技術
}

\section{Applications of Microbubble Technology for Various Fields}

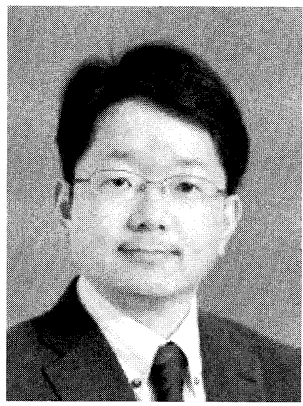

寺坂宏一

慶應義塾大学理工学部応用化学科

干 223-8522

神奈川県横浜市港北区日吉 3-14-1

Koichi TERASAKA

Keio University

3-14-1, Hiyoshi, Kohoku-ku, Yokohama-shi

Kanagawa 223-8522, JAPAN

論文要旨：マイクロバブルは非常に興味深い機能を持っており，その応用分野は多岐にわたる。すでに多 種多様なマイクロバブル発生器が市販されているが, それぞれマイクロバブル発生原理も異なり性能も一様 でないため用途に応じて選択する必要がある。ガス吸収装置のガス分散器として通常のガス分散板の代わり に各種マイクロバブル発生器を使用した場合，ガス吸収速度は大きく改善される。また，酸化鉄微粒子など を懸濁廃水からマイクロバブル浮上分離を用いて回収する方法やマイクロバブルの急速な溶解収縮現象を利 用した固体粒子の製造も可能となった。さらに，均一に浮遊するマイクロバブルに超音波を照射して凝集さ せ，急速浮上させる技術も開発され，マイクロバブルの運動のコントロールが可能になりつつある。本稿で は多分野へのマイクロバブル応用技術の一端を紹介する。

\begin{abstract}
Microbubbles have several useful functions. By utilizing the characteristics of microbubbles, the novel technologies are developed for various applications. There are some principles to produce microbubbles and several kinds of microbubble generators have been proposed. Therefore, the performance of each generator is different each other. By using the microbubble generator instead of standard bubble distributors set a gas absorber, the gas absorption rate was improved well although it depended somewhat on the microbubble generator. To recover the fine iron oxide particles from waste water, the microbubble flotation was developed. By utilizing the rapid shrinkage and dissolution of a single microbubble, the single fine particle was crystallized even in dilute solution. On the other hand, the microbubbles were agglomerated to be swarms by irradiation of ultrasound, and then those escaped rapidly from the liquid phase.
\end{abstract}

The several new microbubble technologies above were introduced in the report.

Key words: microbubble, gas absorption, flotation, crystallization, ultrasound

\section{1 はじめに}

微細な気泡に関する研究は古くから行われているが, 「マイクロバブル」と呼ばれるようになって以来, 養殖 業や湖水浄化などの用途で実用化が進み注目されるよう になった。一方，マイクロバブルの発生原理や物性およ び派生する機能についてはいまだ研究途上であり，実用 化と研究開発の順序が逆転している状況にある。しかし， 観察される現象は非常に興味深く，理論的な解析や解明 が進めば，化学，材料開発，環境対策，臨床医学および

連絡者：寺坂宏一

E-mail : terasaka@applc.keio.ac.jp
バイオテクノロジーなどへの応用展開が期待できる。こ こでは，主として著者の研究プロジェクトを中心にして マイクロバブルの多岐にわたる可能性の一部を紹介す る。

2 マイクロバブル製造技術の発展

マイクロバブル発生器から生成する気泡のサイズやそ の分布は発生器の原理や操作条件によって大きな差が生 じる。寺坂 ${ }^{1)}$ は主なマイクロバブル発生器の原理と性 能について紹介している。

\section{$2 \cdot 1$ 旋回液流式}

円筒状の発生器本体側面から接線方向にポンプを用い 
て液を高速で圧入し, 内部に高速旋回流を発生させる ${ }^{2)}$ 。 この液回転運動に起因した圧力降下を利用し，下端面の 小孔より自吸されたガスは，上端面中央の小孔でのせん 断力により粉砕されマイクロバブルとなる。発生器の構 造はシンプルで，比較的ガス流路および液流路ともに広 いため閉塞などのリスクが小さくメンテナンス性がよ い。すでに牡蠣やホ夕テ養殖，ダム貯水池の水質浄化な どで適用実績がある。

\section{$2 \cdot 2$ スタティックミキサー式}

スタティックミキサーは機械的破砕操作を用いずに流 路内の構造を複雑化し, 液の流通駆動力により発生した 主として渦流由来の大きな粘性せん断力によって気体を 破砕する方法である ${ }^{3)}$ 。他にも液噴流に伴うせん断を利 用して気泡を破砕する方法 ${ }^{4)}$ や充填層 ${ }^{5)}$ に気泡を通過 させる方法なども検討されている。

\section{$2 \cdot 3$ エジェクター式}

エジェクターや水流ポンプでは狭い流路を高速で通過 する液流によって生じる負圧を利用してガスを吸引し， 下流における管路の拡大により生じたキャビテーション によって吸入ガスを破砕してマイクロバブルを製造す る。

\section{$2 \cdot 4$ ベンチュリー式}

ベンチュリー管のように断面積の縮小と拡大をもつ流 路中に気泡を含んだ液を通過させると，急激な減圧に よって気泡は一旦膨張し, 続いて急激な圧力上昇によっ て激しく崩壊され，マイクロバブルを生成する ${ }^{6)}$ 。

\section{$2 \cdot 5$ 加圧溶解式}

従来から廃水処理で利用されている方法で，気液混合 物をポンプで昇圧し，ガス成分を液中に過飽和まで溶解 させる。未溶解気泡を分離し，過飽和液のみを減圧弁を 経て常圧液中にフラッシュさせると, 飽和液中からマイ クロバブルが析出する ${ }^{7,8)}$ 。

\section{$2 \cdot 6$ 極微細孔式}

ポアサイズ約 $1 \mu \mathrm{m}$ のをもつ多孔質ガラス膜で隔て られた流動液中に高圧ガスを注入して直径 $1 \mu \mathrm{m}$ 以下の 微細気泡を生成させる ${ }^{9)}$ 。ただ，流動液中には臨界ミ セル濃度以上の界面活性剂の添加が必要で, 純水に適用 すると気泡サイズは増大する。

\section{$2 \cdot 7$ 超音波付加中空針状ノズル}

注射針状の微細管から生成する気泡に超音波振動を付 与して離脱を促すと生成気泡はマイクロ化される ${ }^{10)}$ 。 大型化には困難な点が多いが，小さな空間内の静止液中 へのマイクロバブル供給が期待できる。

\section{$2 \cdot 8$ 混合蒸気直接接触凝縮式 ${ }^{11)}$}

非凝縮性ガス（たとえば窒素）を含んだ加圧水蒸気を ノズルから冷却水中に噴射すると，サブミリサイズの蒸
気泡が分散される。その直後から蒸気泡は気液界面より 冷却され急速に凝縮して液化するが，非凝縮ガス成分の みが残存してマイクロバブルとなる。余㮃高圧スチーム の有効利用によってマイクロバブルが製造でき，機械的 動力が不要である点に特徴がある。

\section{$2 \cdot 9$ 生成気泡径分布の比較}

上記のうち 7 種類のマイクロバブル発生法について公 表 $^{2,6,8,9,10,12)}$ された気泡径分布の比較を Fig. 1 に示した。 極微細孔式では $1 \mu \mathrm{m}$ 以下の微細気泡が生成している。 超音波付加針状ノズルでは平均 $8.6 \mu \mathrm{m}$, 加圧溶解式は $27 \mu \mathrm{m}$, 旋回液流式で $20 \mu \mathrm{m}$, エジェクター式で $44 \mu \mathrm{m}$, 蒸気凝縮式で $46 \mu \mathrm{m}$, ベンチュリー式で $100 \mu \mathrm{m}$ 程度の マイクロバブルが生成されている。ただし，これらは発 生方式毎に異なる溶液系および操作条件での結果であ る。たとえば供給ガス流量, 駆動液流量および液相の種 類などは統一されていないので，適用する用途などに よって十分な注意と確認が必要である。また, 各発生方 式においてもメーカーや製品によって性能が異なる場合 もある。

\section{3 マイクロバブル技術の特徵とその応用に向けて}

Fig. 1 に示したように，マイクロバブルといってもそ の定義はサイズですら幅がある。従来よく目にする数 $\mathrm{mm}$ から数 $\mathrm{cm}$ の直径をもつ泡（ここではミリバブル， センチバブルと呼ぶ）とは主に次のような性質の違いが ある。

（a）上昇速度が小さい

（b）摩擦低減効果がある

（c）単位体積あたりの表面積が大きい

(d) 自己加圧効果をもつ

（e）急激に溶解および収縮する

（f）表面電位特性が顕在化する

（g）超音波照射により凝集する

（h）生物に対する生理活性をもつ

マイクロバブルを実用的に利用するときにはこれらの 特性を活用することになる。たとえば児玉 ${ }^{13)}$ は船舶壁

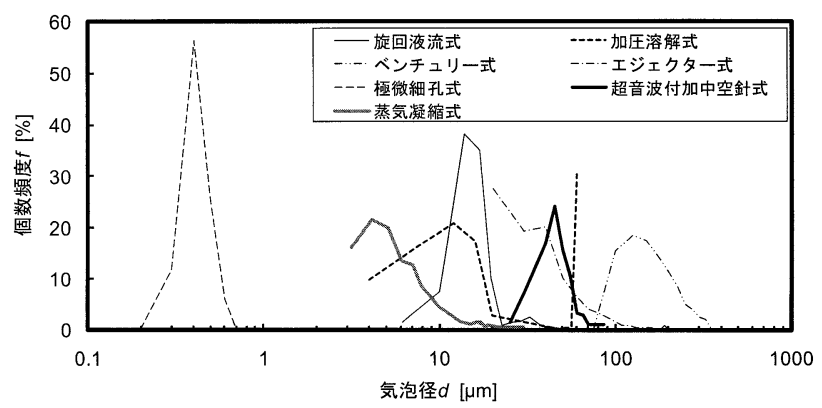

Fig. 1 各種マイクロバブル発生器から生成する気泡径分布 
面からマイクロバブルを分散させて海水との（a）摩擦 低減効果により燃費改善を図った。大成 ${ }^{14)}$ は牡蠣筏に マイクロバブルを分散させ（h）生理活性を刺激して成 長を促進させた。宮本 ${ }^{15)}$ は金属ワークに付着した切削 油の洗浄用に（c）広大な気液接触面積をもつマイクロ バブルを利用した。これらのように工業化の際に重要視 する点は用途に応じて異なるため，最適なマイクロバブ ルも異なると考えてよい。このように，マイクロバブル の性質を理解したうえで実用化を目指した研究開発を行 うことが重要である。

\section{4 ガス吸収装置へのマイクロバブル発生器の適用}

ガス吸収装置の性能は分散気泡と液相との接触面積に 依存するため, (c) 単位体積あたりの表面積が大きいマ イクロバブルは最も直接的に寄与が期待できる。そこで 空気 - 水系の気泡塔型ガス吸収装置に適用した場合につ いて性能評価を行った。

\section{1 ガス溶解性能の比較}

ガスを液中により高速に溶解させるためには，より多 くの気体を, より長い時間, より広い面積で液と接触さ せることが重要である。そこで, 気泡塔（直径 $20 \mathrm{~cm}$, 高さ $1.4 \mathrm{~m}$ ) 底部に代表的マイクロバブル発生器をガス 分散器としてとりつけ（比較のためにミリバブル分散器 として多孔板 $(\phi 1 \times 16$ 孔）も用いた $)$, 空気を水道水中 に分散させた場合の総括物質移動容量係数 $K_{\mathrm{L}} a$ につい て比較を行った。総括物質移動係数 $K_{\mathrm{L}} a$ とは被吸収ガ ス濃度と溶液中の溶存ガス濃度の差が一定のときガス溶 解速度の大きさを示す指標であり，数値が大きいほどガ ス溶解速度が速いことを表す。

Fig. 2 に示したように，多孔板にくらべマイクロバブ 儿発生器の $K_{\mathrm{L}} a$ は数倍〜数 10 倍程度向上した。とくに 低いガス空塔速度 $U_{G}$ では顕著に増加した ${ }^{16) 。 ~}$

\section{$4 \cdot 2$ 所要動力に対する評価}

さらに工業化においてはエネルギーコストの問題も見 逃せない。とくに主なマイクロバブル発生器は前述のよ

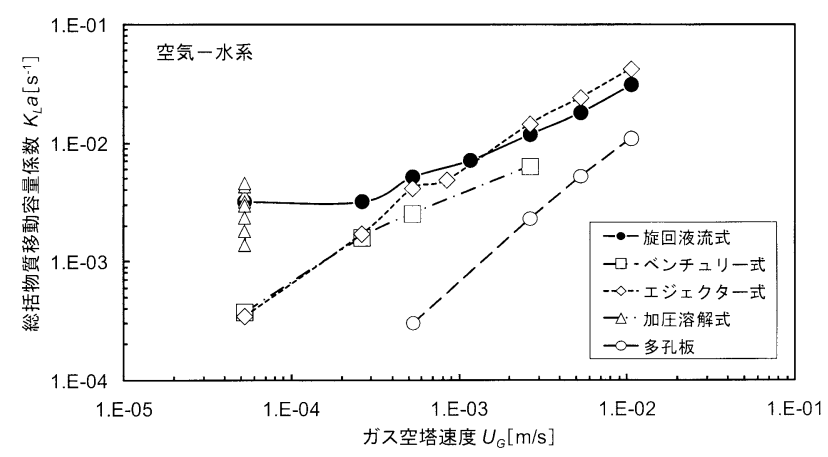

Fig. 2 各種マイクロバブル発生器による物質移動特性の比 較

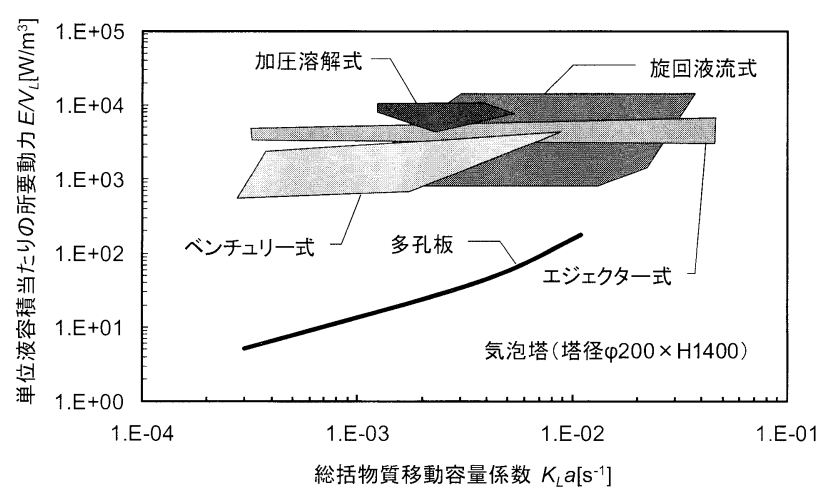

Fig. 3 各種分散器の所要動力の比較

うに液を高速で駆動するためにポンプを使用し，その消 費電力やメンテナンス費用に見合った付加価值を得られ なければ実用化は難しい。

たとえば気泡塔の場合, 多孔板などのガス分散器から 気泡を発生させ液中に送り込むためには，系圧，液ヘッ ドおよび分散器内圧損の総和を上回るガス加圧動力が必 要である。上記で挙げた旋回液流式, スタティックミキ サー, エジェクター式, ベンチュリー式, 加圧溶解式抒 よび極微細孔式では，液を昇圧・駆動するためのポンプ 動力が加わる。

Fig. 3 は各種ガス分散器をもつ同一の気泡塔につい て, 実験的に得られた総括物質移動容量係数 $K_{\mathrm{L}} a$ と単 位液容積あたりの所要動力 $E / V_{\mathrm{L}}$ との関係 ${ }^{16)}$ を示して いる。同じ程度の $K_{\mathrm{L}} a$ を得るためにはマイクロバブル 発生器は従来型発生器よりも大きな付加的動力が必要で あることがわかる。

\section{4 ・3 スケールアップと実現化}

気泡塔のように分散系反応場で物質移動が律速となる 場合には, 塔のサイズや形状の変化により流動状態が変 化するのでスケールアップは慎重に行わなくてはならな い。とくにマイクロバブルを用いた場合, 従来から知ら れている気泡塔内の流動挙動とは異なる可能性もあるの でさらに注意が必要である。

また, 主なマイクロバブル発生器個体の大型化は原理 上難しいものも多く, 大型容器に適用する場合にはナン バリングアップが基本となる。多数の発生器の設置はレ イアウトや接続配管の問題も生じ, メンテナンス性につ いての配慮も必要となる。

さらに今後も新たな原理を利用したマイクロバブル発 生器の登場も考えられ, 単純にそれらの優劣を示すこと は難しいが，工業的用途によって最適な選択が可能にな るように整理が重要である。 


\section{5 多岐にわたるマイクロバブル応用プロセスの実用化 研究}

マイクロバブルの工業的用途としては上記で紹介した ガス吸収 ${ }^{16)}$ に限らず非常に広く, 多岐にわたって現在 もな打広がりつつある。筆者は，固液浮上分離 ${ }^{17,18)}$ ，好 気性活性污泥による廃水処理 ${ }^{19}$ ，W/O エマルション製 造 ${ }^{20)}$, 無機抢よび有機物結晶製造 ${ }^{21)}$, 食品材料製造, カプセル化材料製造など，工業プロセスへのマイクロバ ブルの利用のほか，超音波を利用した制御技術 ${ }^{22)}$ の実 用化を目指して研究を進めているが，ここではその一部 を紹介する。

\section{$5 \cdot 1$ マイクロバブル浮上分離}

マイクロバブルのもつ性質のうち (a) 浮上速度が遅く, （c）単位体積あたりの表面積が大きく，(f）表面電位が 顕著である特徴は固液分離に利用でき，工業廃液からの 有用成分回収を目的として酸化鉄微粉の浮上分離への適 用を検討した ${ }^{18)}$ 。

Fig. 4 はマイクロバブル浮上分離塔である。塔底部に は旋回液流式マイクロバブル発生器（またはガラスボー ルフィルターあるいは単一オリフィス）が設置されてい る。発生器への送液流量 $Q_{\mathrm{L}}$ は $19.0 \mathrm{~L} / \mathrm{min}$ で一定とし, 懸濁微粒子としては酸化鉄 $\alpha-\mathrm{Fe}_{2} \mathrm{O}_{3}$ （平均粒径 $4.54 \mu \mathrm{m}$ ） を用いた。液相として泡沫層が形成される程度（臨界ミ セル濃度の 0.05 倍）に調製した界面活性剂 SDS を微量 含む水道水を用いた。

Fig. 5 に酸化鉄微粒子懸濁液中に，マイクロバブルを

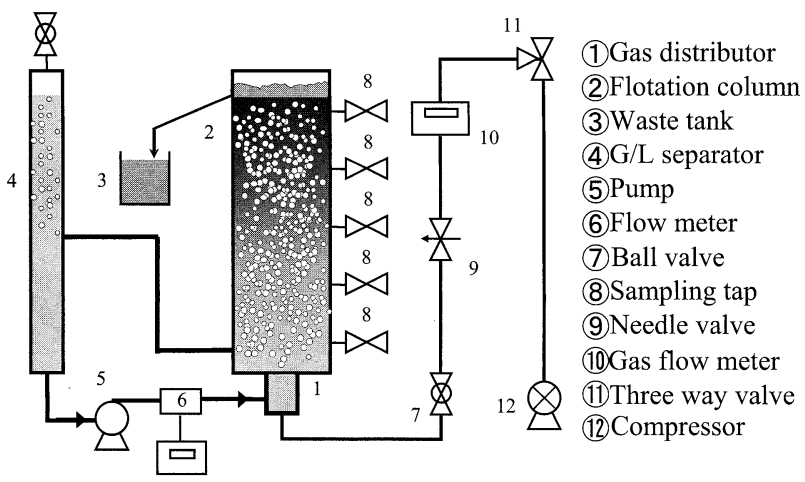

Fig. 4 マイクロバブル浮上分離塔

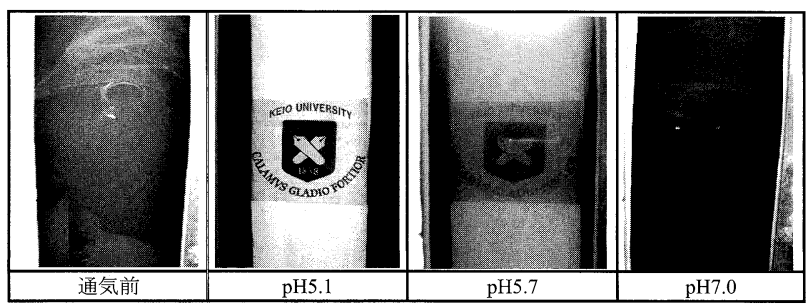

Fig. 5 マイクロバブル通気 60 分後の懸濁液の状況
60 分間通気後の液バルクの写真を示した。左端は通気 前の状態で，不透明な赤褐色である。右端の写真のよう に, $\mathrm{pH}=7.0$ ではマイクロバブルを通気しても微粒子の 分離は進まなかった。一方, $\mathrm{pH}$ を 5.1 に調製した影濁 液に通気すると，背面が透視できるほど微粒子を浮上分 離することができた。この現象は，マイクロバブルと酸 化鉄微粒子表面の電気的特性に起因している。

Fig. 6 にpHによるマイクロバブルと酸化鉄微粒子の ゼー夕電位の変化を示した ${ }^{23.24)}$ 。マイクロバブル表面電 位 ${ }^{24)}$ も酸化鉄微粒子表面の電位 ${ }^{23)}$ も $\mathrm{pH}$ に依存して変 化するが, $\mathrm{pH}$ が約 4.4〜 7.8 のとき,酸化鉄微粒子は正に, マイクロバブル表面は負に带電し，両者間に電気的引力 が働くことがわかる。本研究では，電位が釣り合う $\mathrm{pH}$ が約 5 付近で最も顕著な吸着が観察された。

Fig. 7 に通気装置を 3 種類変更した場合の, バルク液 中の酸化鉄濃度の低下推移を示した。マイクロバブル発 生器, サブミリサイズの気泡を発生するガラスボール フィルター, センチバブルを発生する単一オリフィスの 順に酸化鉄濃度の減少速度は低下し，センチバブルでは ほとんど分離ができなかった。

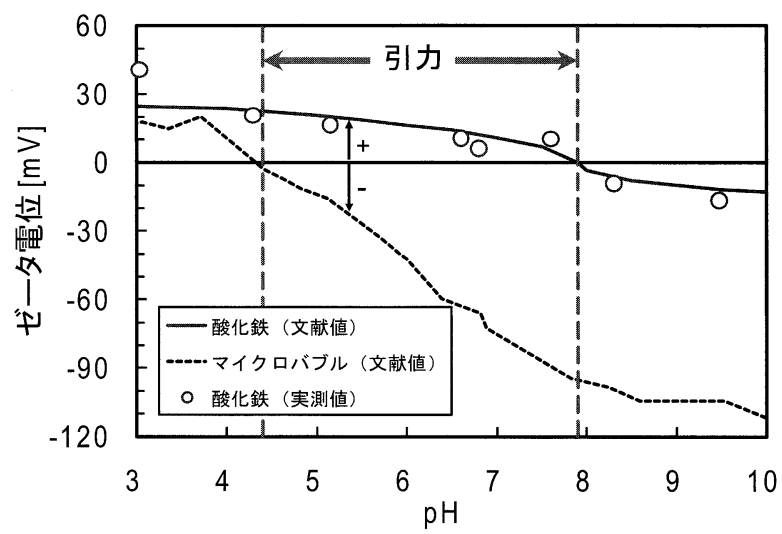

Fig. 6 酸化鉄微粒子とマイクロバブルのゼー夕電位の $\mathrm{pH}$ 依存性

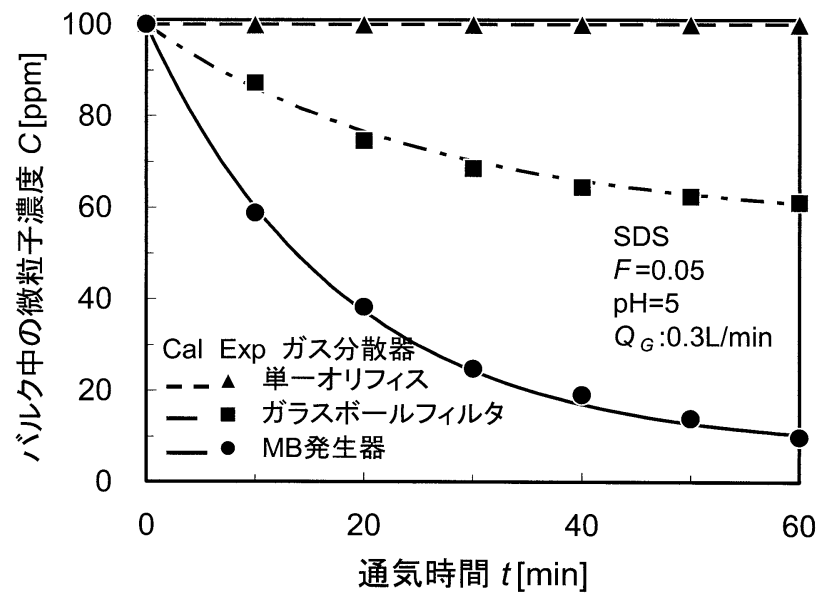

Fig. 7 微粒子回収速度に及ぼす気泡サイズの影響 


\section{$5 \cdot 2$ 超音波によるマイクロバブルの動的操作}

最近マイクロバブルと超音波との相互関係に関する研 究が注目されている。たとえば臨床医学の分野では血液 中にマイクロバブルを造影剂として注入し, 超音波診断 器を用いて血液の流れを可視化する技術が実用化され， 病変の迅速な発見に貢献している。

一方，浮上分離，ガス吸収あるいは気液反応などでは 気液接触面積や液中での滞在時間が非常に重要になる。 そこで，（a）上昇速度が小さく，(f) 表面電位特性が顕 著で，(g) 超音波照射により凝集する特性を利用し，液 中マイクロバブルの動的制御について研究した ${ }^{22)}$ 。

Fig. 8 に実験装置の概要を示した。加圧溶解式マイク ロバブル発生器で製造したマイクロバブルを仕込んだカ ラムの底部に, 超音波発振器（周波数 $2.4 \mathrm{MHz}$ ）を照射 し，カラム内の状況を顕微鏡つき高速度カメラで撮影し た。

Fig. 9 に超音波を照射する前 $(\theta \leqq 0)$ は直径約 $30 \mu \mathrm{m}$ のマイクロバブルは互いに接触せずに分散してい る。ところが超音波照射を開始し， $\theta=0.156$ 秒後にはマ イクロバブル同士が葡萄の房状に凝集しはじめた。さら に 3 秒経過後には大規模な帯状に発達して急浮上した。 ここでマイクロバブル凝集体は多数観察されたが，合体 により生じた大気泡は観察されなかった。さらに超音波 照射を停止すれば元の状態に再分散した。

Fig. 10 にこの現象のメカニズムを示した。水中 (中性) ではマイクロバブルの表面は負に带電しているため，互

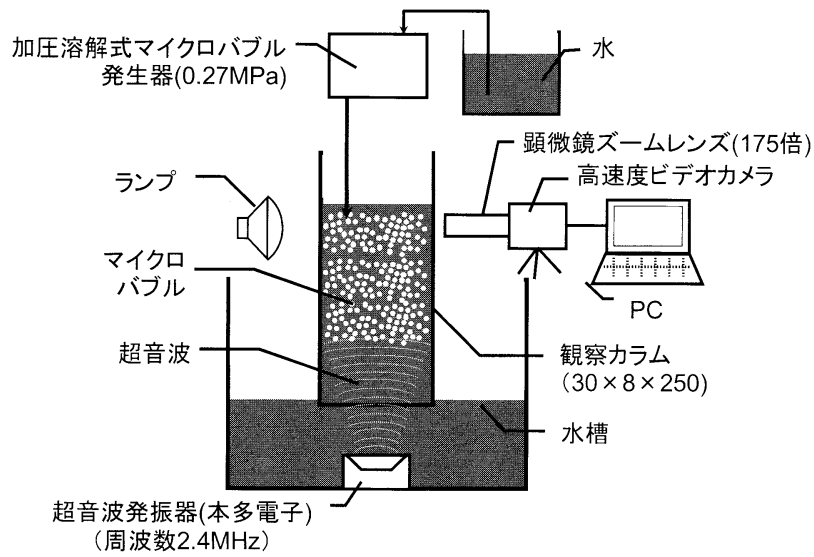

Fig. 8 超音波照射下に扔けるマイクロバブル挙動観察実験

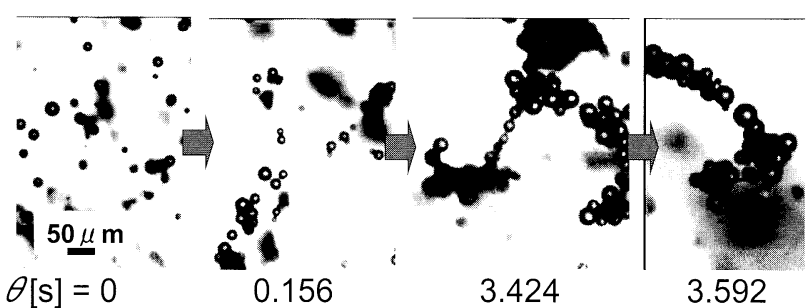

Fig. 9 超音波照射後のマイクロバブルの凝集挙動
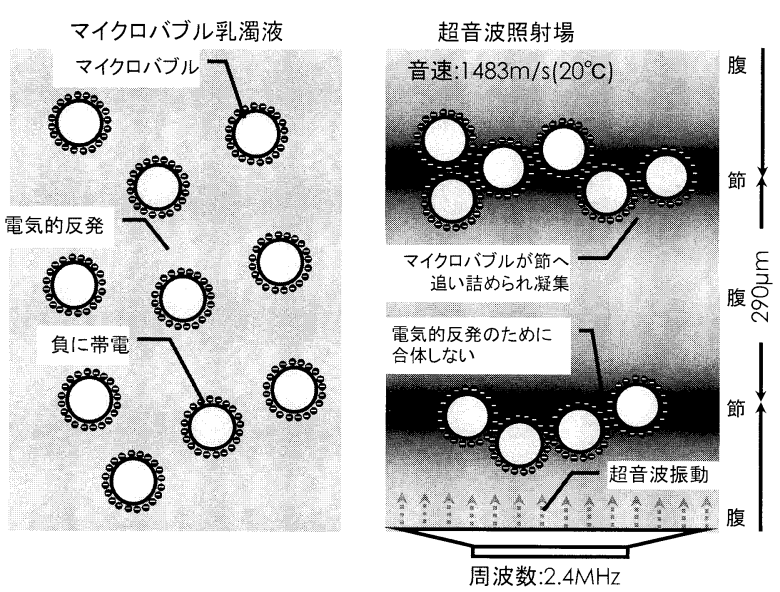

Fig. 10 超音波照射下でのマイクロバブル凝集メカニズム

いに反発し，液中に均一に分散する。この懸濁液に超音 波が照射されると, 粗密波が生じ, マイクロバブルに Bjerknes 力が働き, 約 $300 \mu \mathrm{m}$ 毎に形成された「節」に マイクロバブルが追いやられ帯状の凝集体を形成する。 ところがマイクロバブル表面同士の反発があるため合体 には至らない。この現象を利用すれば，超音波照射の On/Offによりマイクロバブルの急速浮上除去が可能で ある。

\section{$5 \cdot 3$ マイクロバブルによる結晶製造}

マイクロバブルが（e）急激な溶解䇽よび収縮を生じ る性質を利用して, 液相中の溶解成分を固相として析出 させる技術の開発を行った。

Fig. 11 にマイクロバブルの自己加圧効果による急速 溶解メカニズムを示した。気泡内外圧力差 $P_{\mathrm{B}}-P_{0}$ は Young-Laplace の式に従い, 界面張力 $\sigma$ が一定の場合, 直径 $d$ に反比例する。 $d=1 \mathrm{~mm}$ 程度では気泡内圧 $P_{\mathrm{B}}$ は ほぼ系圧 $P_{0}$ に等しいが, $d=1 \mu \mathrm{m}$ になると約 $3 \mathrm{~atm}$ も 高くなる。気泡内压 $P_{\mathrm{B}}$ が高くなるとHenry の法則に従っ て, 気液界面濃度 $C^{*}$ が増加するため推進力 $C^{*}-C$ が
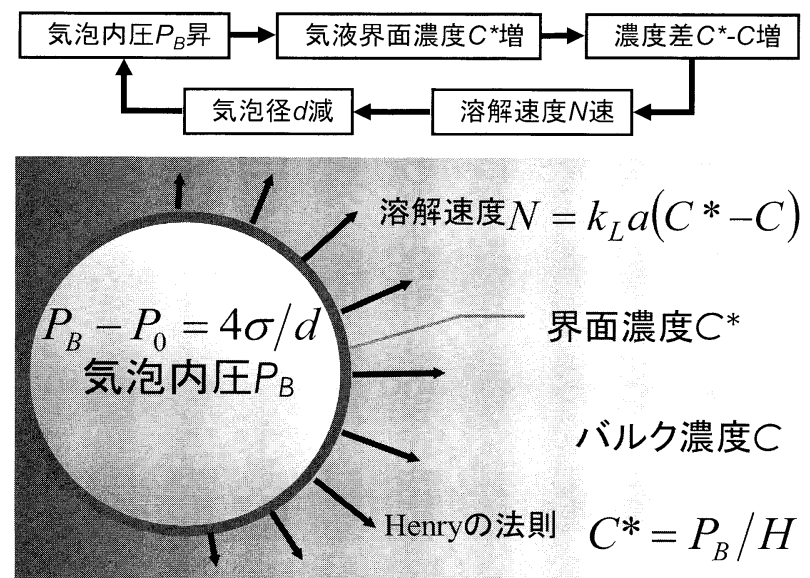

Fig. 11 マイクロバブルの溶解・収縮メカニズム 
気相: 乾燥酸素 液相: $1 \mathrm{wt} \% \mathrm{NaCl}$ 水溶液( $0.2 \mathrm{wt} \%$ アガロースゲル)

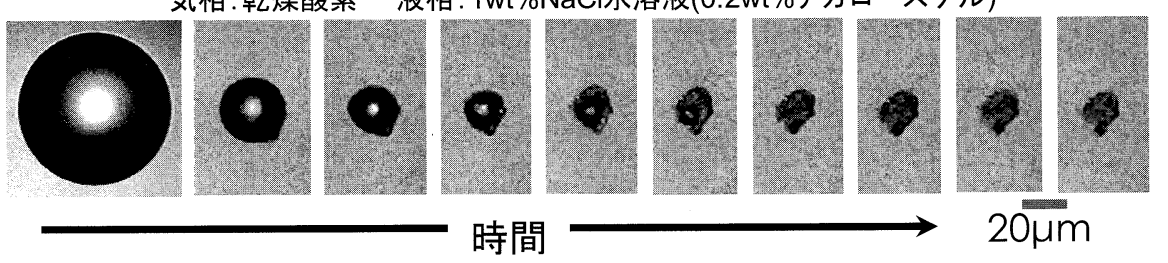

Fig. 12 マイクロバブルの溶解・収縮に伴う固相析出の状況

大きくなり，ガス溶解速度 $N$ は速くなる。気泡体積が 減少するため気泡径 $d$ は縮小しさらに $P_{\mathrm{B}}$ は上昇する。 このサイクルを繰り返すためマイクロバブルは加速度的 に収縮する。

Fig. 12 に希薄食塩水中にマイクロバブルを 1 個置き, その収縮過程のスナップショットを示した。マイクロバ ブルの収縮とともに表面に固相が徐々に析出し，全てが 固体結晶になった後も観察時間内は安定に存在した。液 相中の $\mathrm{NaCl}$ 濃度は飽和濃度より極めて小さく通常なら 析出しないが，マイクロバブルを利用した晶析法では析 出が生じた ${ }^{25)}$ 。

静止液中におかれたマイクロバブル表面には電気的引 力あるいは疎水性をもつ溶質分子やイオンが吸着する。 一方，マイクロバブル内ガスの急速溶解によってマイク ロバブル表面付近の溶液にガス成分濃度が過剩に溶解す る。このとき, 局所的に溶質の溶解度が低下して固体結 晶として析出したと考えられる。

\section{6 最後に}

ここではマイクロバブルの可能性を探る研究の一端を 紹介した。ガスからなるマイクロバブルは気液系のプロ セスへの応用だけでなく，マイクロバブルの持つ機能を 応用した各種機能性材料の開発などにむかい今後の研究 が進展すると予想している。マイクロバブルとして用い るガスや分散させる液体の選択と性質の利用，また圧力 や温度変化ならびに相变化など物理化学的性質の応用, コロイド科学的な視点からの研究など興味は尽きない。

現在著者は日本混相流学会混相流技術リエゾン専門委 員会, マイクロ・ナノバブルの科学と技術的展開研究分 科会, 化学工学会気泡 ·液滴 ·微粒子分散工学分科会, 日本ソノケミストリー学会などでマイクロバブルに関心 をもつ研究者らとともに研究成果を交換，蓄積しつつあ
る。オレオサイエンス分野からの参加もぜひ歓迎したい。

\section{文献}

1) 寺坂宏一, 化学工学, 71, 170-3 (2007).

2) 大成博文，国際特開 WO00/69550（2000）.

3）豊岡正志ら, 特開 2001-62269 (2001).

4）社河内敏彦ら, 日本混相流学会年会 2002 講演論文集, 159-60 (2002).

5）宮原敏郎，水処理技術，46（5），209-15（2005）.

6）藤原暁子，月間エコインダストリー，11（3）, 27-30 (2006).

7）町谷勝幸ら, IDEC Review 1993, 8-16（1993）.

8）オーラテック, http://www.kumin.ne.jp/aura-tec/kihou kei.htm

9）久木崎正人ら, 化学工学論文集, 30, 654-60 (2004).

10）幕田寿典ら, 微細気泡の最新技術, pp.17-29, NTS (2006).

11）寺坂宏一, 特願 2005-289026（2005）.

12）資源開発，http://www.sigen.co.jp/microbubble.html

13）览玉良明，微細気泡の最新技術，241-5，NTS (2006).

14）大成博文, 化学工学, 67, 139-41 (2003).

15）宮本 誠, クリーンテクノロジー, 17, 24-7 (2007).

16）西野貴則, 寺坂宏一, 日本混相流学会年会 2006 講演論 文集，276-7 (2006)

17）寺坂宏一, 新保康行, 混相流, 21，77-83（2007）.

18）寺坂宏一, 青木 駿, 小林大祐, 混相流研究の進展 3 , 53-60 (2008).

19) 平林 藍, 竹内 純, 寺坂宏一ら, 日本混相流学会年 会 2009 講演要旨集, B324（2009）.

20）寺坂宏一, 特許第 4046294 号 (2007).

21）寺坂宏一, 特願 2007-307851 (2007).

22）寺坂宏一, 第 2 回超音波とマイクロバブルの相互作用 に関するシンポジウム要旨集，7-8（2009）。

23) Esumi, K., Idogawa, H.\&Meguro, K., Bull. Chem. Soc. Jpn., 61, 2287-90 (1988).

24) Takahashi, M., J. Phys. Chem. B, 109, 21858-64 (2005).

25）大久保牧子, 佐藤ゆり奈, 寺坂宏一ら, 化学工学会第 40 回秋季大会要旨集, J107（2008）。 